神戸市兵庫運河（新川）に垂下した試験板上のタテジマフジツボから供給される幼生数 の推定

塚本博一

神戸市長田区役所＝653-8570＼cjkstart神戸市長田区北町 3丁目4-3

\title{
Larval output from barnacles, Amphibalanus amphitrite, settled on a test plate in the Hyogo Canal (Shinkawa), Kobe, Japan.
}

\section{Hiroichi Tsukamoto}

Kobe City Nagata Ward Office, Kitamachi, Nagata, Kobe 653-0016, Japan

(Received September 2, 2009; Accepted April 12, 2010)

\begin{abstract}
Barnacles have been recognized as fouling organisms for a long time. Adhering to ship hulls, piers, wharves and cooling-water pipes of power stations, they cause significant industrial damage. Nonetheless, barnacle nauplius larvae constitute a significant food source for the larvae and juveniles of various animal species in the coastal ecosystem. In order to evaluate the contribution of fouling barnacles to this larval output, every two weeks in 2008, the author examined the number of brooded eggs of barnacles settled on a test plate hung in the water in the Hyogo Canal, Kobe. Measurements of sea water temperature and salinity at the observation site, the density of barnacle nauplii in the plankton, and the number of settled barnacles on the test plate were made. The number of nauplius larvae hatched from the barnacles settled on the test plate was thereby estimated to be $100,000 / \mathrm{cm}^{2}$ over the whole year.
\end{abstract}

Key words: barnacle, Amphibalanus amphitrite, growth, reproduction, nauplius, larval output, Japan

フジツボ類は産業上の被害を与えて, 污損生物として 忌避される一方で, 生態学的には食物連鎖の一環として 海洋生物に対して幼生という形で飭生物を供給している と考えられるが, 寄与の程度を具体的に報告した事例は ない。そこで，著者は 1 年間にわたり，試験板を神戸市 の兵庫運河（新川）の水面下に垂下し, 付着したタテジ マフジツボの個体数と近隣の岸壁上のタテジマフジツボ の生殖巣を調べることにより，ノープリウス幼生 1 年間 の放出数を推定した。

\section{実験方法}

2007年11月に試験板（縦 $15 \mathrm{~cm} \times$ 横 $20 \mathrm{~cm} \times$ 厚さ0.3 cm のアクリル板）を神戸市兵庫運河（新川）入江橋の下の 釣り船などの繫船用栈橋に，神戸港大潮最高潮位の下 50 $\mathrm{cm}$ 試験板の上端となるように垂下し，2008年 1 月 24日
から2008年12月26日までの間，ほぼ 2 週間ごとに累積付 着数を調べた。また，水面下の試験板を空中に引き上げ, 試験板の $20 \mathrm{~cm}$ 上方より写真撮影をした。撮影した写真 から繁殖可能サイズである殼口長径 $3.5 \mathrm{~mm}$ 以上の個体数 を計数した。なお、本種の生物学的最小型は款口長径が $3.65 \mathrm{~mm}$ (Iwaki and Hattori, 1987)、3.45 mm (小坂・ 石橋，1980）とされているが、今回の調査では3. $5 \mathrm{~mm} の$ 個体に受精卵がみられたため、3.5 mm以上の個体を生殖 の可能な個体と考えた。なお、前年の予備調査で、調査 地点での試験板に付着した個体はすべてタテジマフジッ ボであることを確認していた。

調査地点において試験板の周囲で $1 \mathrm{~L}$ の海水を採取す るとともに、周辺 $5 \mathrm{~m}$ 以内の栈橋に付着しているタテジ マフジツボの任意の 20 個体の殼口長径を測定しながら採 集し、直ちに $10 \%$ 海水フォルマリンで固定した。その後、 
採取した海水と固定したタテジマフジツボを実験室に持 ち帰り、試水中のノープリウス個体数（4月12日採水分 以降）と、外套内の受精卵またはノープリウス幼生の有 無を実体顕微鏡下で調べた。なお、4月23日、5月 7 日、 8月28日に採集した受精卵を保有する11個体を用いて受 精卵数を計数した。

試験板の周囲で海水温を棒状温度計で測定するととも に海水を $1 \mathrm{~L}$ 採取し、試水の塩分を赤沼式比重計で測定 した。

\section{結 果}

各調查時の水温、受精卵保有率、海域水温から得られ た胚発生所要日数（岩城（1981）による式）から産卵回 数を計算し、試験板に付着している殼口長径 $3.5 \mathrm{~mm}$ 以上 の個体数から試験板付着個体の延心゙産卵回数を計算し、 1 個体あたりの受精卵数の平均值2,600個を乗じて、調 查時毎の産卵個数を推測し、最後に産卵期間の全産卵個 数を推計した（Table 1)。なお、この受精卵個数平均值 については、兵庫運河で調べた11個体（殼口長径5.0〜 $8.0 \mathrm{~mm}$ ）の卵数が 1,454 から 4, 447であり、平均值と標準 偏差は2, 605.8土925.9となったことから2,600を用いた。 また、各調査時の塩分をFig. 1 に示した。

期間中の最低水温は $10.0^{\circ} \mathrm{C} （ 2$ 月 15 日、2 月 26 日）で、 その後、水温が上昇を始め、5月 19 日には $19.5^{\circ} \mathrm{C}$ とな、 8 月になると最高水温 $28.5^{\circ} \mathrm{C}$ （8月 6 日、8月 19 日）に 達した。その後、下降しはじめ、10月 15 日には21. $0^{\circ} \mathrm{C}$ と

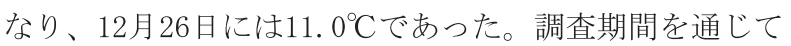
の平均水温は $17.8^{\circ} \mathrm{C}$ であった。期間中の最低塩分は 9.3 PSU、最高塩分は23.9 PSU、平均塩分は19.6 PSUであり、
最も多く観測された塩分帯は20 PSUから21 PSUであった。 調査水域は浅い運河で、小さな河川が流れ込んでおり、 塩分が安定していなかった。

試験板周辺で採集した20個体の中で、初めて受精卵が みられたのは 4 月 3 日である。受精卵またはノープリウ ス幼生をもつ個体の比率は 4 月 24 日には0.55となった。 以後、その比率は 9 月 17 日まで、水温の上昇に従い、 0.85まで緩やかな上昇を示したが、10月 1 日に0.65 とな り、その後、下降した（Table 1)。

本種の胚の発生所要日数が最も短かったのは水温が $28.0^{\circ} \mathrm{C}$ から $28.5^{\circ} \mathrm{C}$ の間で、3.2日であった。年間を通じ ての産卵回数は26.2回であった。繁殖可能な大きさと考 えられた殸口長径 $3.5 \mathrm{~mm}$ 以上の付着個体が、試験板上に 初めてみられたのは 6 月 14 日であった。付着個体数は、 その後、徐々に増え始め、8月 6 日に 416 個体がみられ てからは、急激に増加し、9月17日には870個体と最多 であった。その後、暫減し、12月26日には358個体であっ た（Table 1）。なお、調查期間中で殼口長径が $3.5 \mathrm{~mm}$ 上の付着個体数が最も多かった 9 月 17 日の試験板の写真 をFig. 2 に示した。

試水中にみられたフジツボノープリウス幼生密度を Fig. 3 に示した。試験板および周辺のフジツボがタテ ジマフジツボばかりであったため、ノープリウス幼生も タテジマフジツボであると考えた。1L中にみられたノー プリウス幼生数は 0 個体から860個体の範囲であった。 4 月 12 日から 9 月 2 日までの間は、ノープリウス幼生の 多い時期であり、6月25日は突出し、最も多い860個体 であった。この間の平均個体数は66.3個体/Lであった。

Table 1. Predicted total number of nauplius larvae released from barnacles attached to the test plate.

\begin{tabular}{|c|c|c|c|c|c|c|c|c|c|}
\hline $\begin{array}{c}\text { Date } \\
(2008)\end{array}$ & $\begin{array}{c}\text { Water } \\
\text { temperature } \\
\left({ }^{\circ} \mathrm{C}\right)\end{array}$ & $\begin{array}{c}\text { Days from this } \\
\text { observations to the } \\
\text { next } \\
(\triangle \mathrm{t} i)\end{array}$ & $\begin{array}{c}\text { Predicted numbers } \\
\text { of days required for } \\
\text { enbryo development } \\
\text { (Pfi } i)\end{array}$ & $\begin{array}{l}\text { Fraction of individuals } \\
\text { bearing fertilized eggs } \\
(\theta i)\end{array}$ & $\begin{array}{c}\text { Predicted number } \\
\text { of broods untill } \\
\text { next observation } \\
(\mathrm{B}=\Delta \mathrm{t} i / \mathrm{Pf} i \times \theta i)\end{array}$ & $\begin{array}{c}\text { Total numbers } \\
\text { of barnacles } \\
\text { (N) }\end{array}$ & $\begin{array}{l}\text { Individuals larger } \\
\text { than } 3.5 \mathrm{~mm} \text { in shell } \\
\text { aperture } \\
\text { (n) }\end{array}$ & $\begin{array}{c}\text { Predicted total } \\
\text { number of breeding } \\
\text { barnacles } \\
(\mathrm{Tn}=\mathrm{B} \times \mathrm{n})\end{array}$ & $\begin{array}{l}\begin{array}{c}\text { Predicted number } \\
\text { of nauplii }\end{array} \\
(\mathrm{Na}=\mathrm{Tn} \times 2,600)\end{array}$ \\
\hline 24 Jan & 10.8 & 11 & 19.5 & 0.05 & 0.0 & & 0 & 0 & 0 \\
\hline $5 \mathrm{Feb}$ & 10.2 & 10 & 20.7 & 0.00 & 0.0 & & 0 & 0 & 0 \\
\hline $15 \mathrm{Feb}$ & 10.0 & 11 & 21.1 & 0.00 & 0.0 & & 0 & 0 & 0 \\
\hline $26 \mathrm{Feb}$ & 10.0 & 13 & 21.1 & 0.00 & 0.0 & & 0 & 0 & 0 \\
\hline $11 \mathrm{Mar}$ & 13.0 & 11 & 15.7 & 0.00 & 0.0 & & 0 & 0 & 0 \\
\hline $22 \mathrm{Mar}$ & 12.7 & 12 & 16.2 & 0.00 & 0.0 & & 0 & 0 & 0 \\
\hline $3 \mathrm{Apr}$ & 14.0 & 20 & 14.1 & 0.05 & 0.1 & & 0 & 0 & 0 \\
\hline $23 \mathrm{Apr}$ & 17.0 & 14 & 10.0 & 0.55 & 0.8 & & 0 & 0 & 0 \\
\hline 7 May & 17.0 & 12 & 10.0 & 0.60 & 0.7 & & 0 & 0 & 0 \\
\hline 19 May & 19.5 & 15 & 7.4 & 0.47 & 1.0 & & 0 & 0 & 0 \\
\hline 3 Jun & 18.8 & 11 & 8.0 & 0.62 & 0.9 & & 0 & 0.0 & 0 \\
\hline 14 Jun & 22.5 & 11 & 5.0 & 0.58 & 1.3 & 7 & 1 & 1.3 & 3,000 \\
\hline 25 Jun & 23.0 & 13 & 4.7 & 0.73 & 2.0 & 15 & 3 & 6.0 & 17,000 \\
\hline $9 \mathrm{Jul}$ & 25.2 & 14 & 3.7 & 0.80 & 3.0 & 22 & 9 & 27.1 & 70,000 \\
\hline $23 \mathrm{Jul}$ & 28.0 & 14 & 3.2 & 0.86 & 3.8 & 429 & 39 & 148.2 & 381,000 \\
\hline 6 Aug & 28.5 & 13 & 3.2 & 0.83 & 3.6 & 816 & 416 & 1497.6 & $3,894,000$ \\
\hline 19 Aug & 28.5 & 14 & 3.2 & 0.84 & 3.4 & 1327 & 655 & 2227.0 & $5,790,000$ \\
\hline $2 \mathrm{Sep}$ & 27.0 & 15 & 3.3 & 0.67 & 2.8 & 1143 & 795 & 2226.0 & $5,788,000$ \\
\hline $17 \mathrm{Sep}$ & 27.0 & 14 & 3.3 & 0.85 & 3.9 & 1212 & 870 & 3393.0 & $8,822,000$ \\
\hline 1 Oct & 22.3 & 14 & 5.1 & 0.65 & 1.8 & 1268 & 860 & 1548.0 & $4,025,000$ \\
\hline $15 \mathrm{Oct}$ & 21.0 & 15 & 6.1 & 0.05 & 0.1 & 1032 & 684 & 68.4 & 178,000 \\
\hline 30 Oct & 19.0 & 12 & 7.8 & 0.25 & 0.5 & 971 & 629 & 314.5 & 818,000 \\
\hline $11 \mathrm{Nov}$ & 18.0 & 14 & 8.9 & 0.05 & 0.1 & 858 & 600 & 60.0 & 156,000 \\
\hline $25 \mathrm{Nov}$ & 15.2 & 15 & 12.4 & 0 & 0.0 & 738 & 486 & 0.0 & 0 \\
\hline $10 \mathrm{Dec}$ & 16.0 & 16 & 11.3 & 0 & 0.0 & 625 & 439 & 0.0 & 0 \\
\hline $26 \mathrm{Dec}$ & 11.0 & & 19.1 & 0 & & & & & \\
\hline total & & & & & 26.2 & & & & $29,942,000$ \\
\hline
\end{tabular}




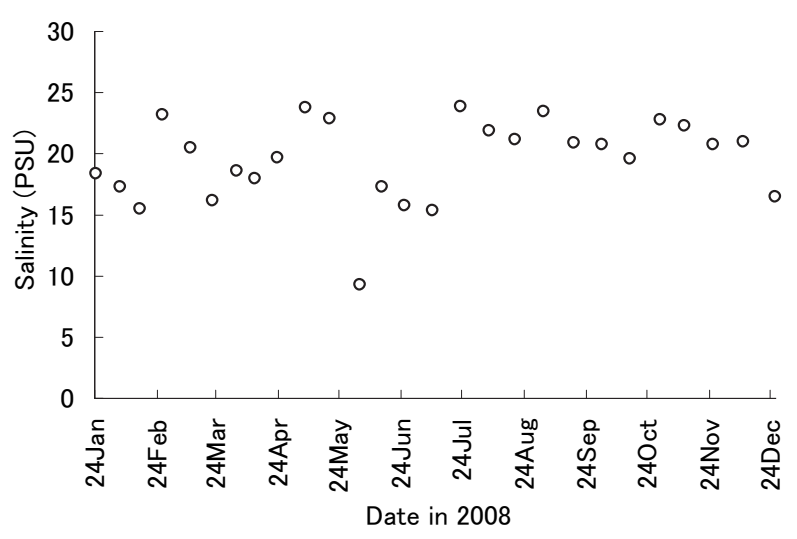

Fig. 1 Fluctuations in salinity (PSU) around the test plate in 2008.

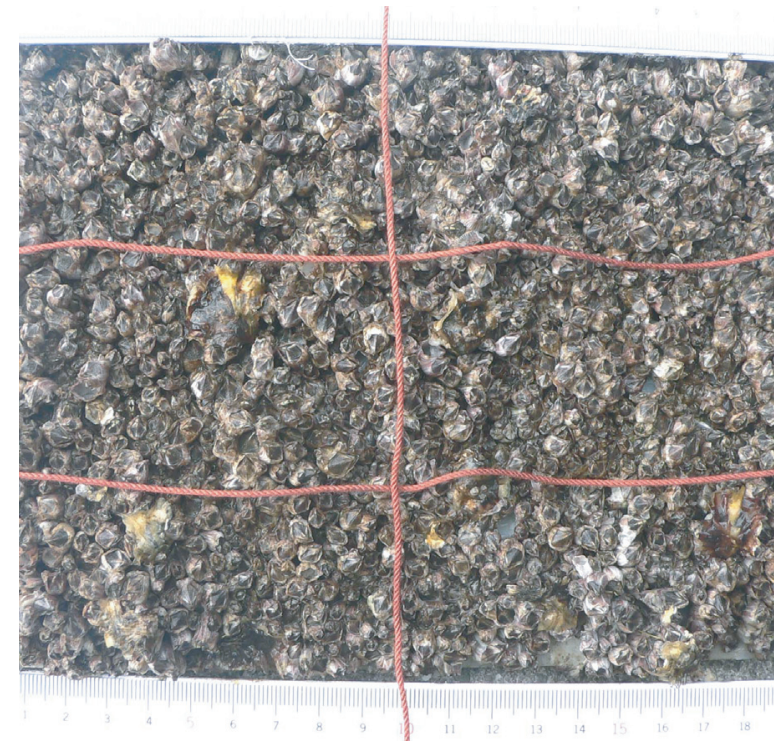

Fig. 2 Grown and recently settled barnacles, Amphibalanus amphittrite, on the test plate set on Nov. 20, 2007 in the Hyogo Canal (photographed on Sep. 17, 2008).

\section{考 察}

Patel and Crisp（1960）は、本種を自然では産卵し ない冬期に採集し、水温と餌（Artemia larvae）の条件 を変えて繁殖実験を行った結果によると、十分に餌を与 えていれば、 $17.5^{\circ} \mathrm{C} ら 31.5^{\circ} \mathrm{C}$ の間の水温で全ての個体 が 2、3 週間以内に産卵し、40日の実験期間中に $1-2$ 回の産卵を確認したとしている。兵庫運河で追跡個体数 の繁殖がみられた時期の水温は $14.0^{\circ} \mathrm{C}$ か $28.5^{\circ} \mathrm{C}$ の間で あった。その間の受精卵の平均保有率は 0.6 であり、水 温の上昇に伴い受精卵保有率も上がった。この間の産卵 回数は26.2回である。次に、三重県のタテジマフジッボ の繁殖は、少し温度範囲が広く、繁殖回数が 21 回から 26 回である（岩城、1981）。また、福井県丹生浦では繁殖 時の水温は $18^{\circ} \mathrm{C}$ か $28^{\circ} \mathrm{C}$ （安田、1968）、油壷湾では $24^{\circ} \mathrm{C}$ か $27^{\circ} \mathrm{C}$ (平野・大串、1952) であり、スエズ運河 では、本種の繁殖期間の水温は $17^{\circ} \mathrm{C}$ か $30^{\circ} \mathrm{C}$ であ (Shalla et al., 1993)。年間平均水温が $25^{\circ} \mathrm{C}$ と当水域

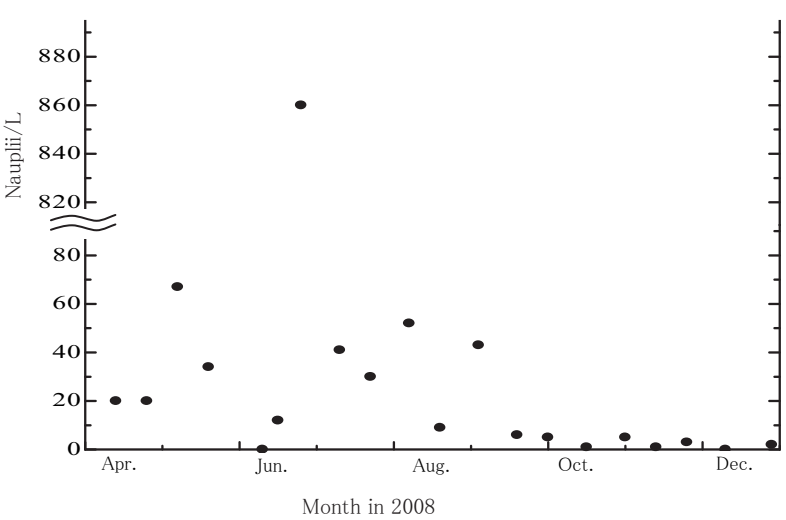

Fig. 3 Fluctuations in density of barnacle nauplius larvae around the test plate during the test period.

に比べて高い南モザンビークでは、水温が $21^{\circ} \mathrm{C}$ 前後の時 の受精卵の保有率は0.45から0.58であるが、以後水温の 上昇に伴い受精卵の保有率が減少し、水温が $28^{\circ} \mathrm{C} や 30^{\circ} \mathrm{C}$ では0.25に下がった（Luti1o，2007）。温排水の影響の ある神戸港水域で繁殖率を調べた結果によると、水温が $30.1{ }^{\circ} \mathrm{C}$ 超えると繁殖率は下がり（塚本、1982）、モザ ンビークの例と同様であり、必ずしも水温が高いほど繁 殖率が高いとは限らない。

本種の塩分と繁殖との関係について調べた報告は少な い。当水域での繁殖時の平均塩分は19.2 PSUであり、繁 殖回数は26.2回であった。一方、兵庫運河より西へ $5 \mathrm{~km}$ の須磨ヨットハーバーでの平均塩分は28. 5 PSUであり、 繁殖回数は26.8回であった（その間の水温 $14.2^{\circ} \mathrm{C}$ から $\left.26.0^{\circ} \mathrm{C}\right)($ 塚本、1982)。これらの平均塩分の違いは、繁 殖に影響を及ぼしていないと考えられた。

兵庫運河では 1 個体当たりの一対の卵塊当たりの卵数 (以後、受精卵数) は1, 454個から4,447個であり、平均 受精卵数は2, $600 \pm 900$ 個であったため、放出ノープリウ ス個体数を推計する際には、1回に2,600個体として計 算した。本種の受精卵数については2,000から3,000個 (加戸・平野、1979)、殼口長径が大きい個体ほど受精卵 数が多く3,600から4,200個（Lutilo，2007）、4,800個 (Barnes and Barnes, 1968) との報告がされている。兵 庫運河での受精卵数が2, 600個であったことより、2007 年11月から神戸市兵庫運河入江橋下に垂下した $15 \mathrm{~cm} \times$ $20 \mathrm{~cm} \times 0.3 \mathrm{~cm}$ の試験板においては、2008年 6 月 14 日か ら12月26日までの間に29, 942,000個のノープリウス幼生 を放出していると考えられ（Table 1)、1 $\mathrm{cm}^{2}$ ありに すると100,000個体となる。

相模湾で 7 月から 10月の間に、カタクチイワシの食性 を調べた三谷（1988）は、消化管内容物の中で、蔓脚類 は2. 15\% で第 5 位の出現率であり、全長が $30 \mathrm{~mm}$ 前後の 個体では瞢脚類キプリス期幼生等を多く選択して摂慨し ているとしている。また、北海道太平洋沿岸海域でサケ 幼稚魚の食性を調べた関（2005）は、2000年 6 月に標津 沖水深 $3 \mathrm{~m}$ で捕獲したサケ稚魚の胃内容物の $0.02 \%$ 、 水深 $6 \mathrm{~m}$ で捕獲したサケ稚魚の $0.15 \%$ をフジツボのキプ 
リス幼生が占めており、採集場所によってはキプリス幼 生が50\%を占めている例もあったとしている。また、フ ジツボの幼生の分布については、小海（2008）が千葉県 小湊の海岸から58 mの間の砂浜砕波帯で採集した小型 プランクトンの中では、優占して出現したのはフジツボ のノープリウス幼生で、それぞれ $37.2 \%$ から $40.1 \%$ 占 めていたとしており、安田（1986） は福井県丹生浦湾で のフジツボ類の幼生量はノープリウス、キプリスとも湾 外と湾内とで違いがなかったとしている。また、天然餌 料としてカイアシ類と共にフジツボ類のノープリウスを 与えて稚仔魚等の養殖に利用している例（吉田、1985） や、クルマエビ養殖の初期餌料としてフジツボを殼ごと 砕いて、卵、ノープリウス幼生、および、その他の微小 な組織片を与え、ゾエアからミシスに成長させた例（藤 永・橘高、1966）がある。

タテジマフジツボの繁殖時期は今まで述べてきたよう に 6 月から11月の間であり、初夏から晚秋にかけてノー プリウス幼生を放出している。一方、ムラサキイガイの 産卵期は神奈川県久里浜においては 4 月（坂口・梶原、 1988）、神奈川、岩手、長崎においては10月から 3 月、 福井においては11月から 2 月（劉・梶原、1983）とされ ており、ムラサキイガイは秋から春にかけて、沿岸の生 態系に卵を餌生物として供給していると考えられる。夕 テジマフジツボは、夏季に産卵するマガキなどと相俟っ て、沿岸水域での餌生物を供給していると考えられた。 フジッボの幼生は沿岸での食物連鎖の一部を担うものと 考えられる。また、フジツボの幼生は種苗生産時の初期 餌料などにも用いられてきた。試験板を利用してフジッ ボ類の産出する幼生の量を試算した結果、大量であるこ とが明らかになった。今後は、海岸に既に生息している フジツボ類の幼生産出状況を把握することが必要である。

\section{引用文献}

Barnes, H. and M. Barnes (1968). Egg numbers, metabolic efficiency of egg production and fecundity; local and regional variations in a number of common cirripedes. J. Exp. Mar. Biol. Ecol., 2, 135-153.

藤永元作・橘高二郎 (1966). クルマエビ幼生の変態と餌料. 日
本プランクトン研究連絡会報，13，83-94.

岩城俊昭 (1981)。本邦で一般的なフジツボ数種の繁殖生態. 付着生物研究, 3 (1), 61-69.

Iwaki, T. and H. Hattori (1987). First maturity and initial growth of some common species of barnacles in Japan. Bull. Fac. Fish Mie Univ., 14, 11-19.

加戸隆介 - 平野礼次郎 (1979). 付着生物浮遊期幼生の飼育法. 付着生物研究, 1 (1), 11-19.

小坂昌也・石橋 公 (1980). 清水港岸壁上でのタテジマフジ ツボの成熟、成長、死亡の付着層間の比較. 付着生物研究, 2 (1), 9-14.

小海莱梨絵（2008）。小湊研修報告一砂浜砕波帯におけるプラ ンクトン相の特徵. 日本海洋生物研究所年報, 2008，42-61.

Lutilo, C. (2007). Distribution, abundance and reproduction of the Indo-Pacific acorn barnacle Balanus amphitrite. J. Mar. Biol. Ass. U.K., 87, 724-727.

三谷 勇 (1988). 相模湾シラス漁場におけるカタクチイワシ の食性. 日本水産学会誌, 54 (11), 1859-1865.

Patel, B. and D. J. Crisp (1960). The influence of temperature on breeding and the moulting activities of operculate barnacles. $J$. Mar. Biol. Ass. U.K., 39, 667-680.

劉 明淑・梶原 武 (1983).ムムラサイガイの繁殖生態．付 着生物研究, 4 (2), 11-21.

坂口勇・梶原 武 (1988). ムラサキイガイの付着生態. 付 着生物研究, 7 (1/2), 23-30.

関 二郎 (2005). 北海道太平洋沿岸域における幼稚魚の摂餌 特性と餌料環境に関する研究. さけ・ます資源管理センター 研究報告, 7, 1-104.

Shalla, S. H. A., A. F. A. Ghobashy, and R. G. Hartnoll (1993). Studies on the barnacle Balanus amphitrite Darwin,1854 (Cirripedia) from lake Timsah in the Suez Canal. Crustaceana, 68 (4), 503517.

塚本博一 (1982)。温排水域におけるタテジマフジツボの繁殖。 付着生物研究, 4 (1), 5-8.

塚本博一（2005）。野外におけるタテジマフジツボの萝脚運動 に及ぼす水温、塩分、珪藻密度の影響. Sessile Organisms, 22 (1), 7-11.

安田 徹（1968）。福井県丹生浦湾における污損生物 IIII. タテ ジマフジツボの生態について。 日本生態学会誌，18 (1), 27-32.

吉田儀弘（1985）。天然プランクトン。日本栽培漁業協会事業 年報, 昭和60年度, 134-136 